\title{
THE SMALL-SCALE SPECIES MOBILITY IN CALCAREOUS GRASSLANDS - EXAMPLE FROM SOUTHERN POLAND
}

\author{
WOJCIECH BĄBA \\ Institute of Nature Conservation, Polish Academy of Sciences \\ Mickiewicza 33, 31-120 Kraków, Poland \\ e-mail: wbaba@iop.krakow.pl
}

(Received: December 23, 2003. Accepted: September 18, 2004)

\begin{abstract}
In this paper I use the different measures of species mobility to describe the fine small-scale dynamics of calcareous grassland built mainly by perennial species and developed in the highly heterogeneous habitat of calcareous rocks. The community showed the low dynamics on a plot-scale $\left(100 \mathrm{~m}^{2}\right)$ and a high one on the scale of $1 \mathrm{~m}^{2}$. However, the studied species differed greatly in calculated indices: turnover rate, (T; 6-64), residence time (RT; 0.5-21.8 y) and carousel time (CT; 4-420 y) as well as the observed tendency to persistence on the spots (PERSIST) and their re-colonisation (AGAIN). This allowed to distinguish the three groups of species: (1) "core species" characterized by high frequency and low T and high CT and RT values, which determine the low dynamics of a community on the plot scale, (2) species with intermediate mobility rate and (3) the group with high mobility rate. The observed cumulative frequencies of all the studied species $\left(\mathrm{CF}_{o b s}\right)$ were much lower than expected under the random re-assignation model $\left(\mathrm{CF}_{R R}\right)$. Moreover, they were also lower than those predicted by random immigration model $\left(\mathrm{CF}_{R I}\right)$. The results showed that the "complex carousel" model rather than "single carousel" one explained better the small-scale dynamics of calcareous grasslands.
\end{abstract}

KEY WORDS: carousel model, community dynamics, fine-scale turnover, calcareous grasslands, Poland.

\section{INTRODUCTION}

The knowledge about non-directional spatial and temporal changes in the community is not only essential for understanding a plant community function, but also for determining the baselines for studies on long-term responses of comunity to environmental changes (Palmer and Rusch 2001). These changes can be associated with: weather conditions (year-to-year weather fluctuations, especially the periodical occurrence of extreme conditions, such as severe drought, flooding etc., Grubb 1988; Huber 1994; Rusch and van der Maarel 1992; van der Maarel and Sykes 1997), formation of empty spaces convenient for colonization by species (van der Maarel and Sykes 1997), ecological characteristics of plants which form a community (van der Maarel and Sykes 1993; Tamm et al. 2002), regional species pools (number of potential colonizers; Glenn and Collins 1992).

Species-rich plant communities which seem stable and homogenous on a large scale appear to be very mobile on a smaller one (van der Maarel and Sykes 1997; Herbén et al. 1993; Sykes et al. 1994; Klimeš 1999), particularly in dry species-rich grasslands, built mainly by annuals and biennials (van der Maarel 1996). In the "carousel model", as proposed by van der Maarel and Sykes (1993, 1997), all species present in the community "move around" the com- munity and eventually reach all microhabitats in a relatively short time. These authors introduced the term "cumulative species richness", i.e. the number of species occurring in the area over a series of consecutive years, and "cumulative frequency", i.e. the sum of plots in which species occurred during the study period.

The carousel model was aimed to explain how do differences in pattern of mobility between species forming the community promote the coexistence of a high species number even in a small area (Rusch and van der Maarel 1992; van der Maarel and Sykes 1997). The results of many theoretical studies, such as patch - coexistence models (Caswell and Cohen 1991) or models based on cellular automata (Czárán and Bartha 1992), confirmed that species coexistence was promoted by interspecific differences in spatial mobility. However, the field research by Herbén et al. (1994) and lately Otsus and Zobel (2002) showed that although the studied grasslands were composed of coexisting species with high and low mobility, it was impossible to determine whether this variation underlied the species richness of these grasslands.

Palmer and Rusch (2001) pointed out that the development of a general model of fine-scale dynamics was hindered by confusion of terms and the use of different types of indices to assess the mobility. They developed direct estimates of carousel time, residence time and expected cumu- 
lative frequency and tested their interrelationships with the other indices used in the literature.

In this study I used the measures of species mobility developed by Rusch and van der Maarel (1992) and Palmer and Rusch (2001) to elaborate the model of dynamics of species-rich calcareous grasslands in southern Poland, dominated by perennial species and characterized by a high spatial heterogeneity. The interrelationships between the measured estimates and calculated indices of species mobility were also explored. In addition, I made an attempt to estimate the mobility patterns of chosen calcareous grassland species and their role in community dynamics.

\section{METHODS}

\section{Study site}

The study was carried out in the Ojców National Park, southern Poland, in the years 1997-2001. The study area lies in the southern part of the Kraków-Częstochowa Upland [19 $\left.20^{\prime} \mathrm{E} ; 50^{\circ} 13^{\prime} \mathrm{N}\right]$. The xerothermic grasslands form small patches on steep, rocky, calcareous slopes of the Prądnik valley, where they are accompanied by shrubs and trees. They are of both natural and semi-natural origin and represent Origano-Brachypodietum pinnati Medw.Korn. and Kornaś 1963 and Koelerio-Festucetum rupicolae Kornaś 1952 communities. The investigated patch of grassland is situated on SW steep slope, inclined $45-50^{\circ}$ The substratum is Jurassic limestone covered with loess where shallow soils of rendzina type have developed.

The preliminary studies have shown that this grassland is very rich in species. In the period 1997-2001, the number of species per $100 \mathrm{~m}^{2}$ was 95 , and per $1 \mathrm{~m}^{2}-15-32$. The mean sod height ranged from 12 to $20 \mathrm{~cm}$ and the mean dry biomass was $150-350 \mathrm{~g} / \mathrm{m}^{2}$.

The estimated pool of xerothermic and thermophilous species of the "Grodzisko" rock, where the study plots have been established, was 108 vascular plants species $(55 \%$ of the total "xerothermic pool" of the Ojców National Park (the classification of xerothermic species followed Michalik 1979).

The site is characterized by strong thermal contrasts: in summer the air temperature reaches even $60-70^{\circ} \mathrm{C}$ (Klein 1974), whereas in winter the vegetation is subject to a freeze because of the shallow snow cover. The lowest mean temperature was recorded in 1997. The mean annual precipitation varied from $730.0 \mathrm{~mm}$ in 1999 to $874.4 \mathrm{~mm}$ in 1998 (Partyka 2003).

Calcareous grasslands on "Grodzisko" had been maintained since the 13th century by extensive grazing, mainly by cows, sheep and goats, and sometimes mowing. As the result of cessation of this traditional management in the 1960s, many xerothermic grassland patches have been overgrown with trees and shrubs. Additionally, many of them were planted with Pinus sylvestris L. (nomenclature after Flora Europaea; Tutin et al. 1964-1995) and Fraxinus excelsior L. Since the 1980s calcareous grasslands have been given active protection in the ONP. They are maintained mainly by regular cutting of trees and shrubs.

\section{Field methods}

In 1996 I established $1001 \times 1 \mathrm{~m}$ plots in 10 parallel transects (10 contiguous plots per each of transects). They were separated from each other by $2.5 \mathrm{~m}$ wide belts. The investigated plot is included in a wider experiment aimed to examine the influence of different active protection measures on the biodiversity of calcareous grasslands and a chance of restoring them. I studied the species mobility pattern only in a scale of $1 \mathrm{~m}^{2}$. The community dynamics is strongly scale-dependent; therefore, the results obtained in my study can be related only to the scale of $1 \mathrm{~m}^{2}$.

Since 1997, at the end of June in five consecutive years, the presence of all vascular plant species have been detected in these plots, using with a wooden $1 \times 1 \mathrm{~m}$ frame. For the purpose of the present research I selected 34 species, typical of calcareous grasslands, but with different life histories and occurring with different frequency in the studied plot. Their ecological characteristics are shown in Table 1 .

\section{Species mobility measures}

To estimate the pattern of dynamics of the selected species I used the chosen mobility indices which can be found in the literature. Their review and characteristics are shown in Table 2. The number of quadrates in which the given species appeared $(I)$ and disappeared $(E)$ throughout the study period was counted. Additionally, I noted the number of quadrates where a species appeared for the first time $(\mathrm{NEW})$, the quadrates where species re-appeared after initial extinction (AGAIN) and - quadrates, which were occupied continuously during the whole study period (PERSIST). This last value is not identical with "persistence", a term commonly used in the literature, estimated on the basis of qualitative measure of point autocorrelation in time (Herbén et al. 1993; Palmer and Rusch 2001). Species is considered extinct when present (it forms aboveground parts) in $i-1$ year and absent in $i$ year. It was not examined whether a given species survived as underground organs; however, most of the re-appearances were probably the effect of re-sprouting after the dormancy period. For each species the mean frequency $(P)$ and the mean cumulative frequency $\left(C F_{\text {obs }}\right.$; van der Maarel and Sykes 1993, 1997) were estimated. The values $I, E$ and $P$ were used to calculate the turnover rate (T; Rusch and van der Maarel 1992), the direct estimates of residence time $(R T)$ and carousel time $(C T)$, as proposed by Palmer and Rusch (2001).

To compare the mobility of the studied species between years a CA analysis was used with the CANOCO package (ter Braak and Smilauer 2002). The values of $I, E$, NEW, AGAIN and PERSIST, directly measured for each species in the field in consecutive years, were used in this model. Then, the species were classified among groups with different mobility rates, determined on the basis of $T, R T$ and $C T$ values, calculated for all the study period. A hierarchical clustering, Ward's method with city-block (Manhattan) distance, was used (Lepš and Šmilauer 2000).

To explore the interrelationships between the species mobility indices, an r-Pearson correlation was used.

\section{Direct measures of cumulative frequency under null-model}

Cumulative frequency is one of the most commonly used indices for estimation of species mobility. In many publications, the researchers often compare the observed cumulative frequency $\left(C F_{\text {obs }}\right)$ with the predicted one for a hypothetical plant community where random shifting of all the species is expected (Geisselbrecht-Taferner et al. 1997; van 


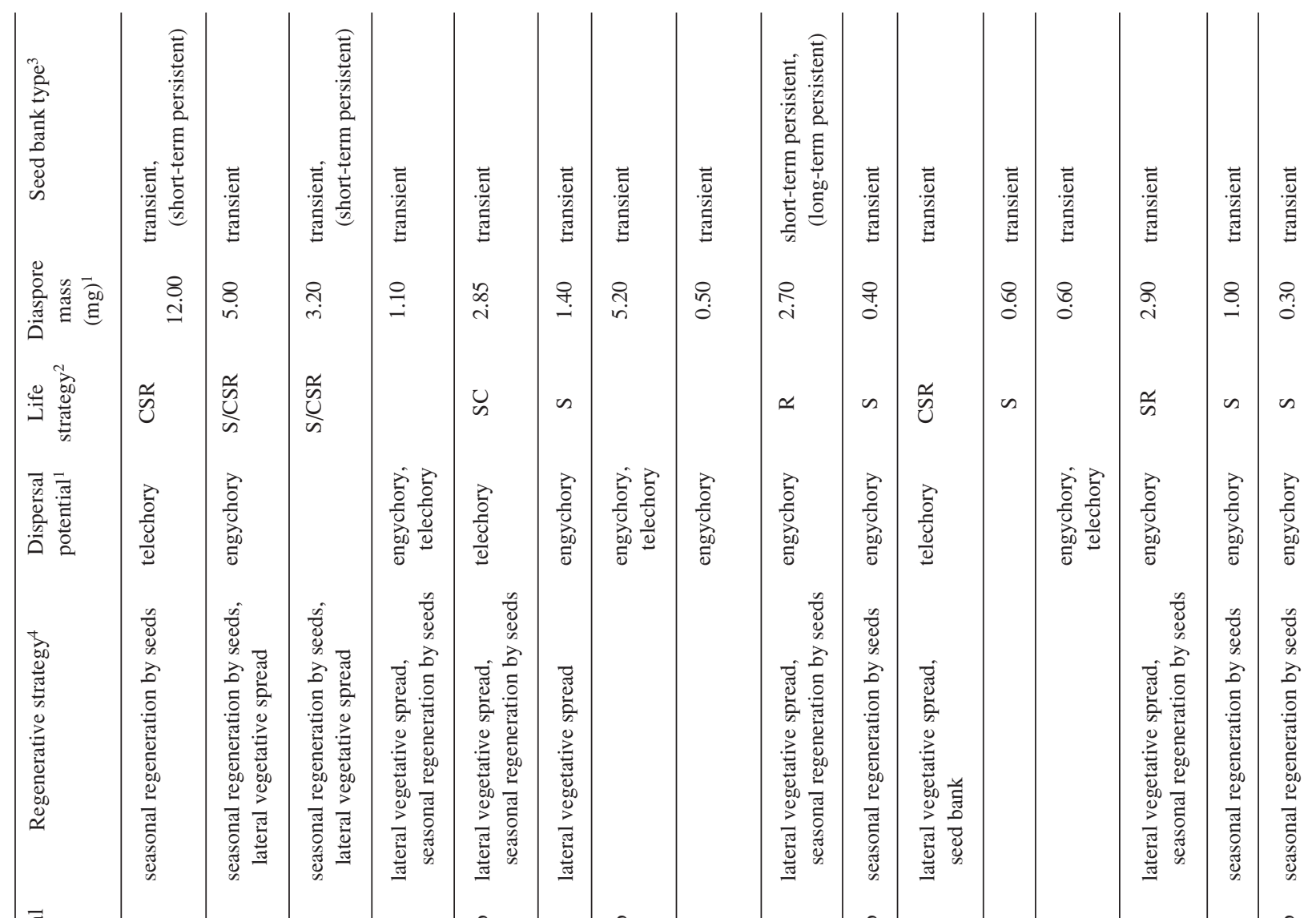

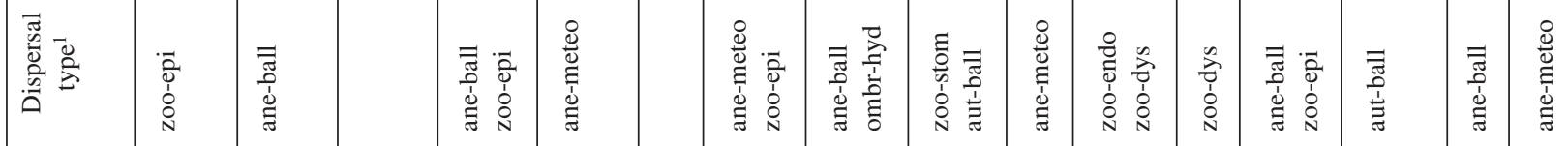

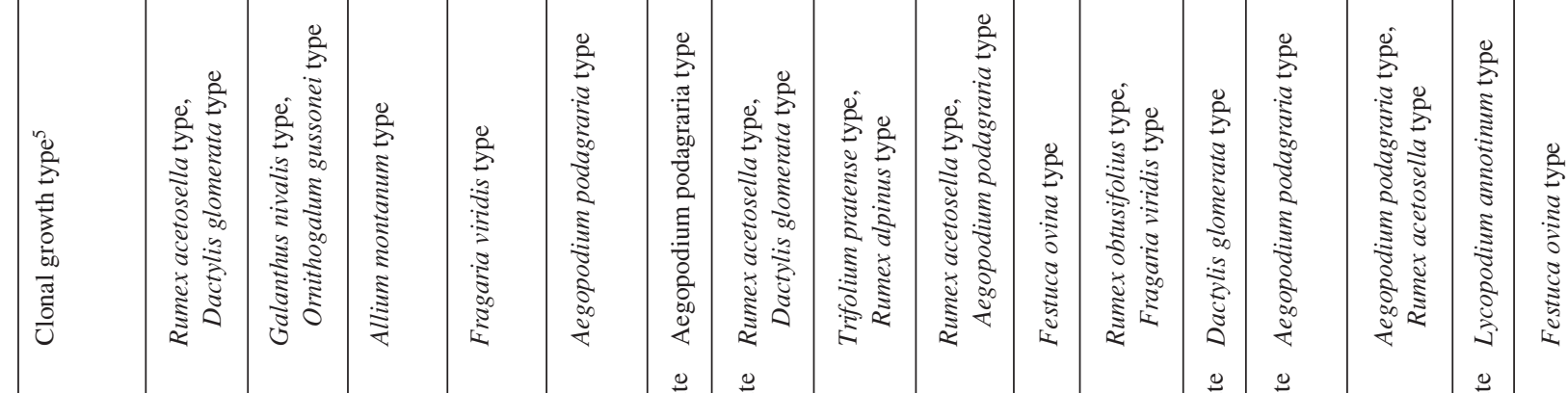

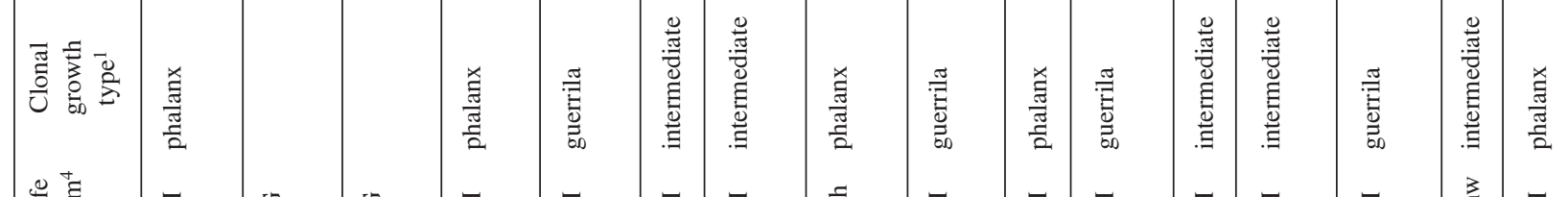

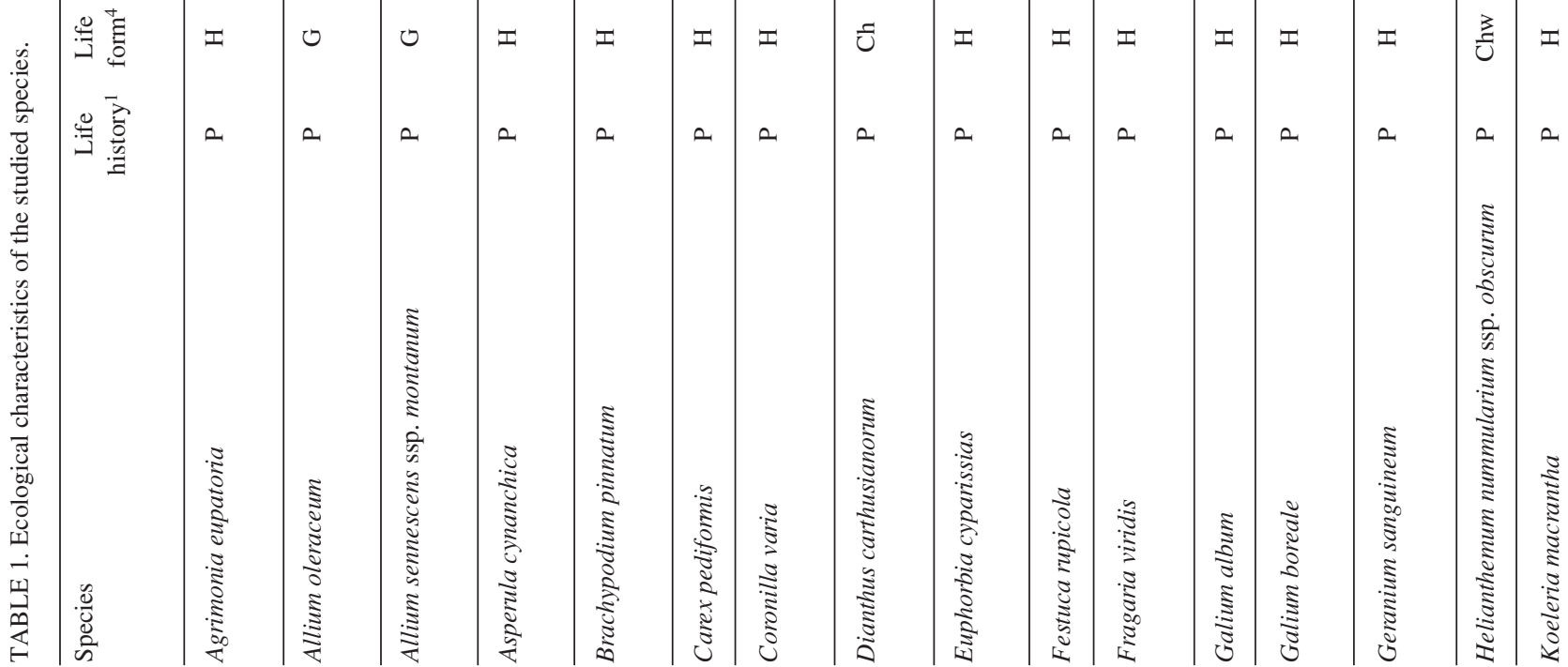




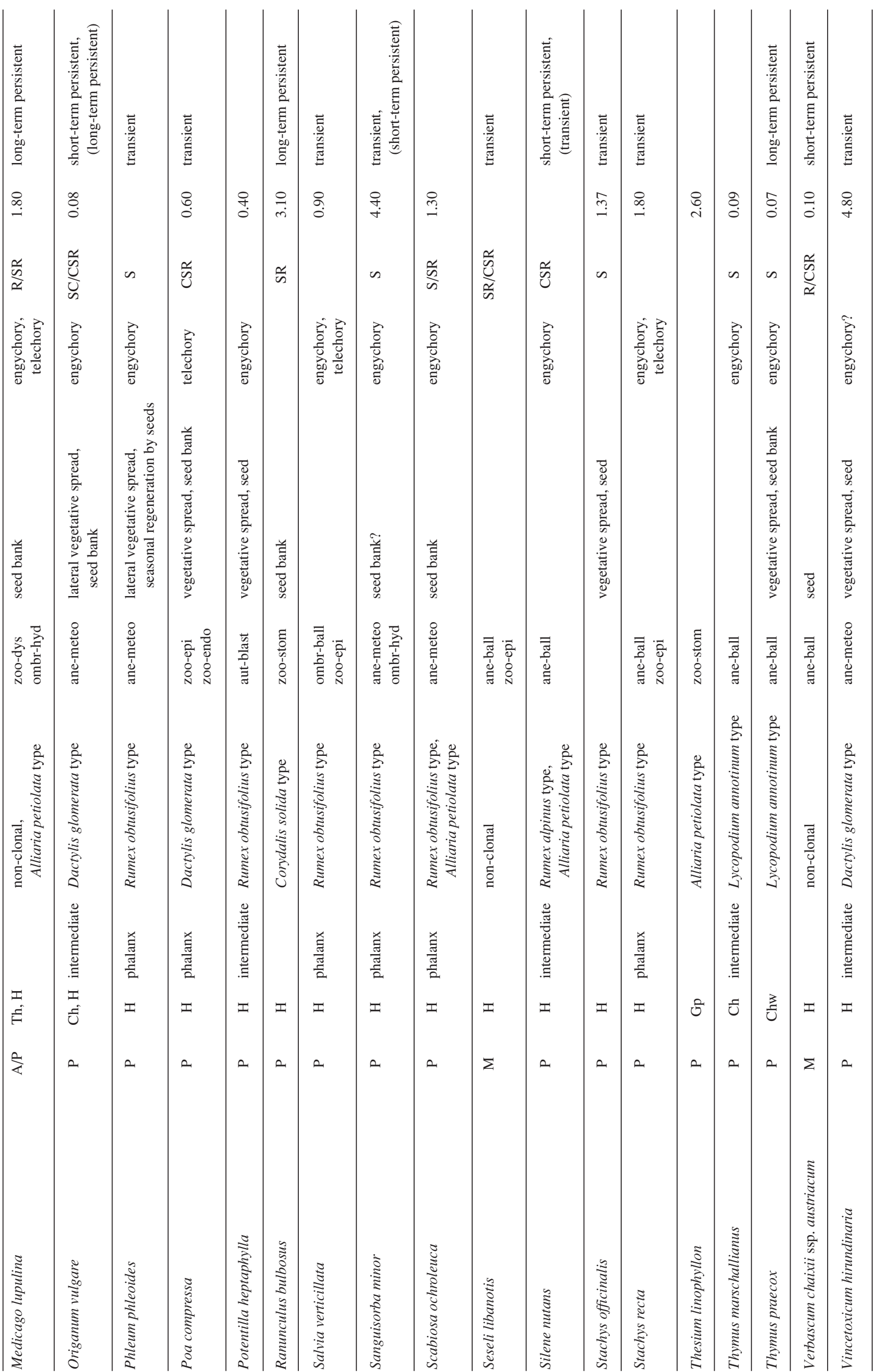


der Maarel and Sykes 1997; Klimeš 1999; Palmer and Rusch 2001).

Van der Maarel and Sykes (1997) considered the three possible models of frequency accumulation of species: (1) random accumulation - based on yearly random allocation of species occurrences, (2) minimal accumulation - occurrences of species are always in the subplots where the species was found earlier unless there is an increase in frequency and new plots have to be included, (3) maximal accumulation - species are located always into new plots until all plots are occupied. In the light of the results of studies in plant communities dominated by perennials and occurring in the heterogenous environment, the random accumulation model (elaborated for communities built mainly by annuals and biennials), seems unrealistic. However, it is a good null hypothesis for testing to what extent does the observed species dynamics differ from randomness (Klimeš 1999; Palmer and Rush 2001).

In the random immigration model, as proposed by Palmer and Rush 2001, the species tend to persist in the previously occupied locations but all the empty locations are equally available for colonization. They proposed a simple direct method of calculating the cumulative frequency expected under random reassignment and random immigration models. These indices were used in the presented paper to elaborate the model of calcareous grassland dynamics (Table 2).

\section{RESULTS AND DISCUSSION}

\section{Changes in the species richness}

The analysed calcareous grassland was very stable on plot scale $\left(100 \mathrm{~m}^{2}\right)$. The mean total number of vascular plant species per $1 \mathrm{~m}^{2}$ ranged from 17.2 in 1997 to 20.7 in 2001 and those of Festuco-Brometea class, from 13.0 in 1997 to 16.1 in 1999 (Fig. 1). At the same time, the mean cumulative species richness increased from 17.2 to 30.1 . The statistically significant $(\mathrm{P}<0.001$; Wilcoxon match-pair test) changes in species number occurred only during the years 1997-2000. However, the detailed analysis of the investigated plot revealed a high species mobility on the quadrat scale $\left(1 \mathrm{~m}^{2}\right)$. It confirmed a frequently observed decline in the species mobility rate with an increase in the sample area (Herbén et al. 1993, Klimeš 1999, Pärtel and Zobel 1995).

\section{Mobility characteristics}

As shown in Table 3, the species under study differed greatly in all the mobility characteristics tested. The values
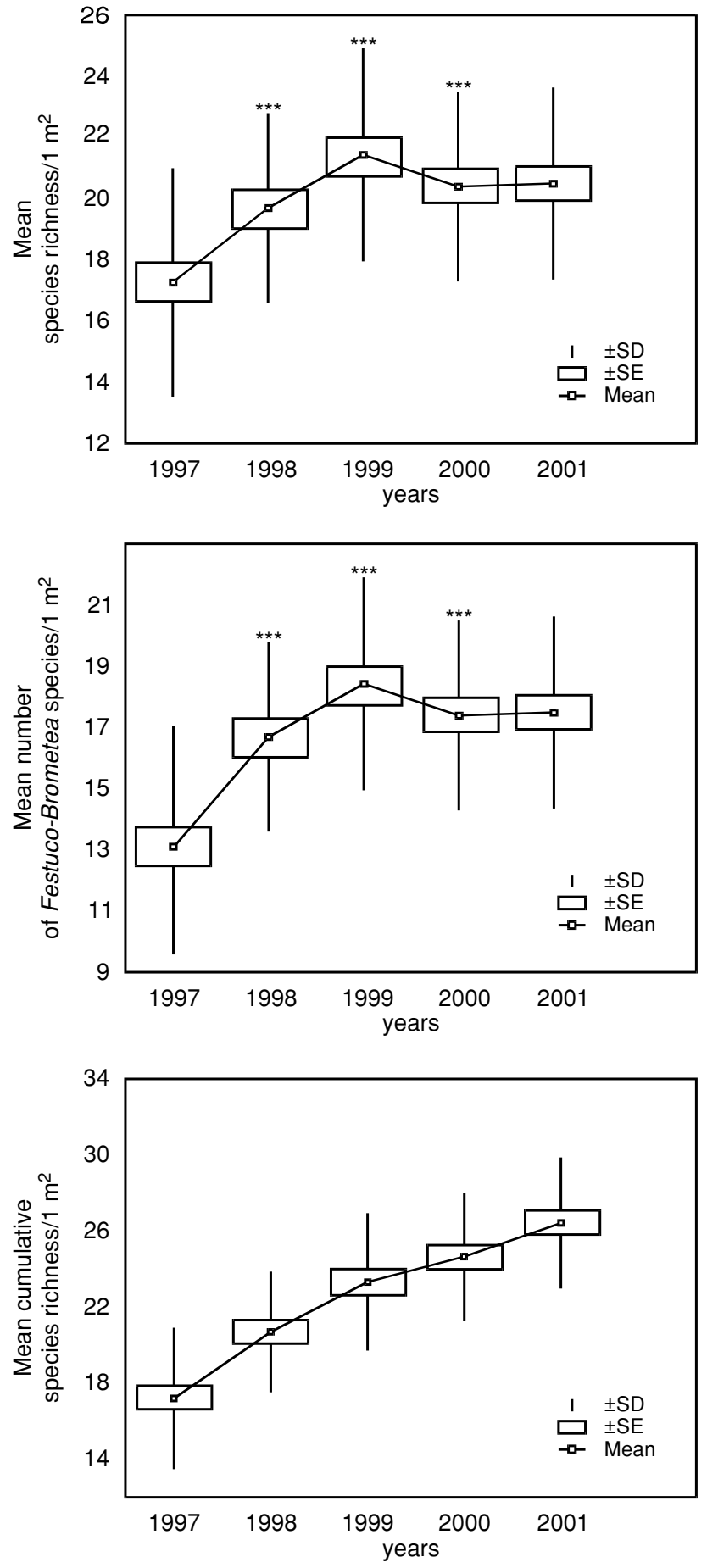

Fig. 1. Mean and mean cumulative species richness $/ 1 \mathrm{~m}^{2}$. The significant differences (Wilcoxon's match-pair test) with the preceding year are shown.

Abbreviations

Life history: A - annual, M - monocarpic perennial (of duration of 2 years or, usually more), P - polycarpic perennial. Raunkiaer's life forms: Chw woody chamaephyte, p - semiparasite. Regenerative strategy: seasonal regeneration by seed, lateral vegetative spread (offsets remaining attached to the parent for a long period, usually for more than one growing season), Dispersal type: ane-ball - ballanemochory (released from plant by wind), ane-meteo meteoanemochory (able to fly), aut-ball - ballautochory (spread by mechanisms of turgescence or dessication), zoo-epi - epizoochory (transported by attachment to animals), zoo-endo - endozoochory (transported within animal intestines), zoo-dys - dyszoochory (seeds are intentionally eaten by predators), zoo-stom - zoostomatochory (myrmecochory; dispersed by ants). Dispersal potential: telechory - long-range dispersal, engychory - short-range dispersal. Clonal growth type: A. Root-derived organs of clonal growth: Trifolium pratense type, Alliaria petiolata type, Rumex acetosella type, Ranunculus ficaria type; B. Stem-derived organs of clonal growth. Ba. Long-lived stems: Lycopodium annotinum type, Festuca ovina type, Rumex obtusifolius type, Rumex alpinus type, Dactylis glomerata type, Aegopodium podagraria type. Bb. Short-lived stems: Fragaria viridis type, Caltha palustris type, Asperula odorata type. Bc. Below-ground tubers: Calystegia sepium type, Lycopus europaeus type, Adoxa moschatelina type, Corydalis solida, Colchicum autumnale type, Corydalis cava type, Bulboschoenus maritimus type, Galanthus nivalis type, Ornithogalum gussonei type, Tulipa sylvestris, Allium montanum type. Literature: 1 - Hensen (1997), 2 - Grime (2001), 3 - Thompson et al. (1997), 4 - Grime et al. (1995), 5 - CLO-PLA1, Klimeš et al. 1997. 
TABLE 2. Review of mobility measures used

where: $I$ - immigration events; $E$ - extinction events; $i$ - immigration rate (probability of occupying an empty plot per year), $e$ - extinction rate (probability of an occupied plot becoming empty in the next year), $p$ - equilibrum frequency, expressed as a proportion of sites or quadrats, $N$ - is the number of sites (in my case quadrats); $P_{o}-$ initial frequency of the species, $p_{t}$ is the frequency in year $t$ and $i_{t}-$ is the immigration rate in year $t$.

\begin{tabular}{l} 
Mobility measure \\
\hline Turnover \\
(Rush and van der Maarel 1992) \\
Residence time \\
Relative Residence Time \\
(Geisselbrecht-Taferner et al. 1997; \\
$\quad$ van der Maarel E., Sykes M. T. 1997; Klimeš 1999):
\end{tabular}

Carousel Time

Relative Carousel Time

Cumulative frequency

(van der Maarel, Sykes, 1993, 1997)

\section{Description}

Sum of immigration and extinction events

$$
T=I+E
$$

The average time species spent on the microsite (in years)

$$
R T=\frac{1}{e}
$$

The average time species spent on the microsite under random reassigment model

$$
R R T=\frac{1-p}{e}
$$

Length of time untill all sites but one is occupied by particular species [in years]

$$
C T=-\frac{\log (N)-\log \left(1-P_{0}\right)}{\log (1-i)}
$$

Length of time untill all quadrats but one is occupied by particular species under random reassigment model:

$$
R C T=\frac{\log (1-p)}{\log (1-i)}
$$

Proportion of quadrats occupied by a species since the start of the study

The direct measure of expected $C F$ under random reassignment model (species are randomly re-assigned to microsites; Palmer \& Rush 2001):

$$
C F(\mathrm{RR})=1-\Pi\left(1-p_{t}\right)
$$

The direct measure of expected $C F$ under random immigration model (the species tend to persist in previously occupied location but all the empty location are equally available for colonization; Palmer \& Rush 2001):

$C F(\mathrm{RI})=1-\left(1-P_{0}\right) \Pi\left(1-i_{t}\right)$ of turnover rate ranged from 6 for Allium senescens L. ssp. montanum (F.W. Schmidt) Holub. and Stachys officinalis (L.) Trevis., to 68 for Seseli libanotis (L.) W.D.J. Koch. The calculated values of the carousel time were similar to, and in some cases smaller than those obtained by Palmer and Rush (2001). A reason for this disparity was probably the smaller number of quadrates ("seats in the carousel"). However, the obtained values showed that the time which was needed for the full carousel turnover in the investigated small patch of calcareous grassland $\left(100 \mathrm{~m}^{2}\right)$ was different. It ranged from 4 to more than 400 years and residence time from 0.5 to over 21 years (Table 3 ), which allowed one to distinguish the three groups of species, characterized by low (A), intermediate (B) and high mobility rate $(\mathrm{C}$; Fig. 2). The matrix species (core species; Herbén et al. 1993; Sykes et al. 1994; constant species, van der Maarel, Sykes 1997) with high frequency, high values of $R T$ and $C T$ greater than 100 years, and low turnover were assigned to the first group. Its typical representatives were Festuca rupicola Heuff., Carex pediformis C.A. Mey and Brachypodium pinnatum (L.) P. Beauv. The matrix species are longlived and in spite of the high diaspore production they reproduce mainly in a vegetative way (Fig. 2, Table 1). In the research carried out in the Ukrainian steppe by Vorontzova and Zaugolnova (1985) the individuals of Festuca rupicola reached $30-80$ years of age and were characterized by a slow growth and small changes in the size of tussocks over a many-years' period. The long-term observation of the permanent study plots in calcareous grassland in Bohemian Karst, dominated by Festuca vallesiaca Schleich. ex Gaudin i Carex humilis Leyss. (Hroudová and Prach 1994), confirmed the high stability of this community connected with the life-histories of these species. The low mobility rate of the highly expansive grass Brachypodium pinnatum (Bobbink and Willems 1987, Table 3), in spite of its high frequency, resulted probably from microhabitat heterogeneity within the investigated plot. The very low values of mobility indices of Galium boreale L., Stachys officinalis L. and Geranium sanguineum L., resulted from their low frequency in the studied community and unsuitable habitat conditions. A distinct subgroup was formed by species typical of calcareous rocks vegetation: Allium sennescens subsp. montanum, Thymus praecox Opiz, Thesium linophyllon L., Koeleria macrantha (Ledeb.) Schult. and Helianthemum nummularium (L.) Mill. subsp. obscurum (Čelak.) Holub, which had a very low dynamics rate (CT=57.8-72.6, Fig. 2).

Group B consisted of species with intermediate mobility ( $C T=26-50 ; T=21-40$, Fig. 2), occurring in both rock grasslands and xerothermic grasslands, such as: Stachys recta L., Salvia verticillata L., Potentilla heptaphylla L., Medicago lupulina L., Phleum phleoides (L.) H.Karst. and 


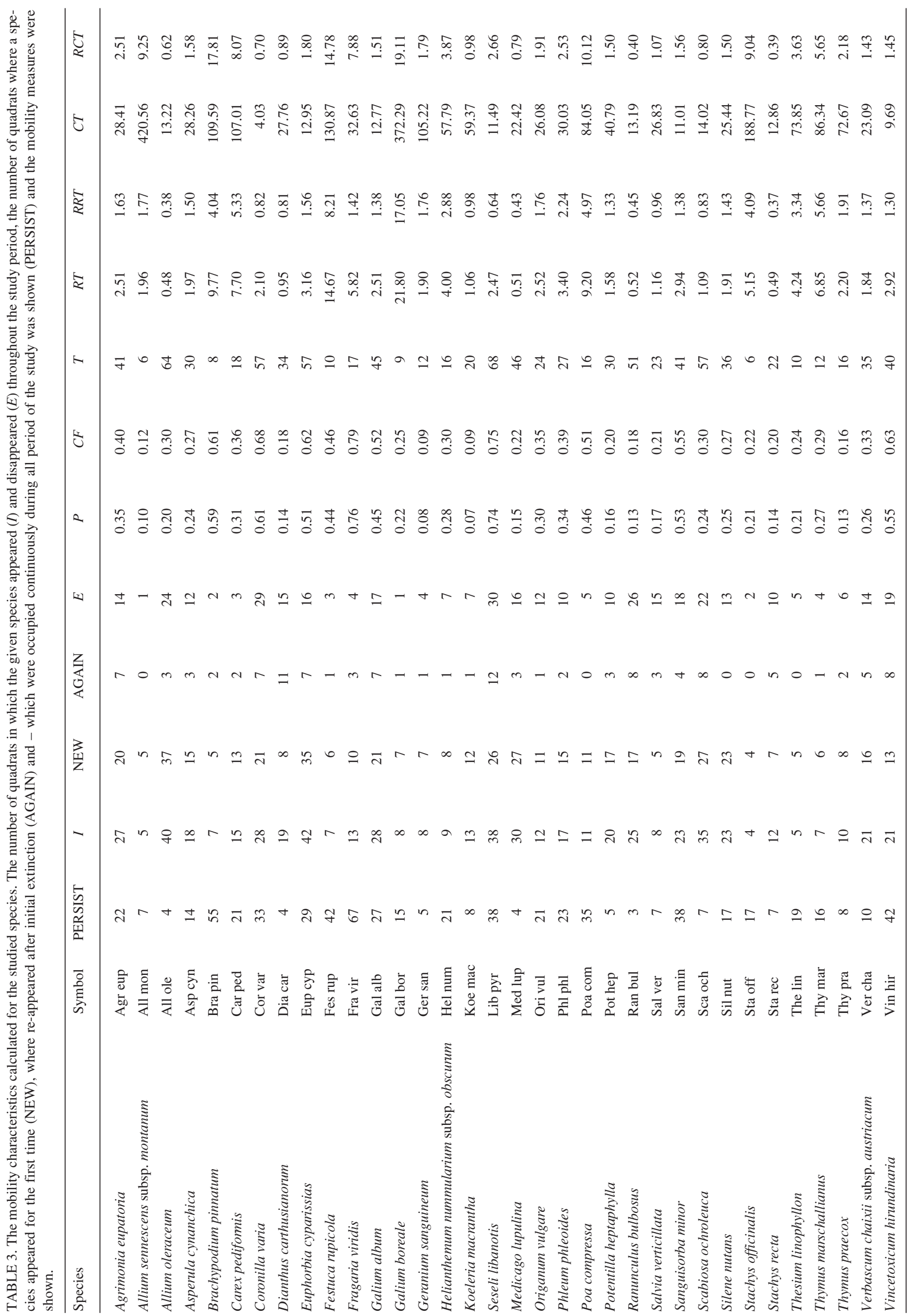




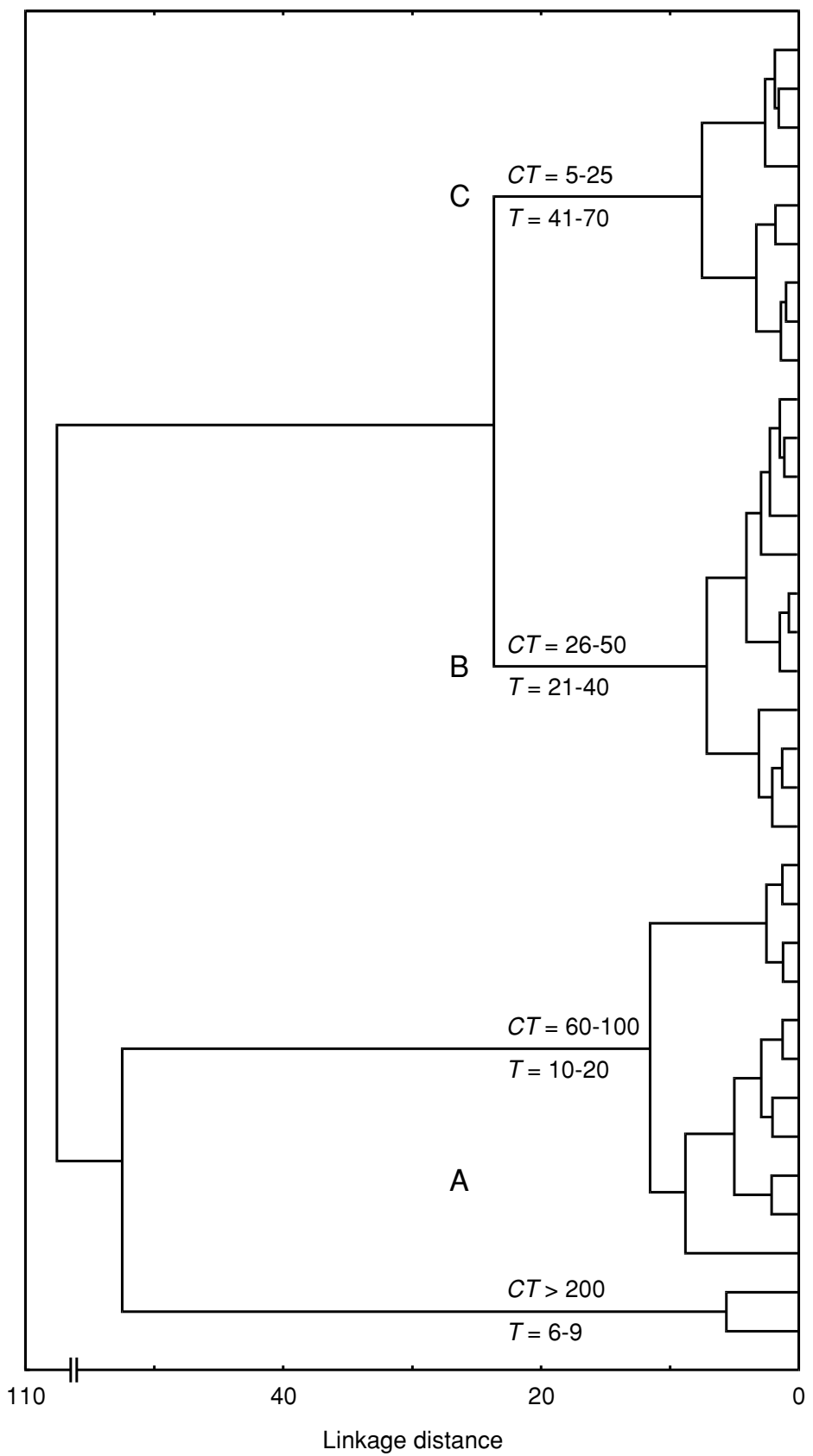

Allium oleraceum

Euphorbia cyparissias

Scabiosa ochroleuca

Seseli libanotis

Coronilla varia

Ranunculus bulbosus

Galium album

Sanguisorba minor

Vincetoxicum hirundinaria

Agrimonia eupatoria

Silene nutans

Verbascum chaixii ssp. austriacum

Dianthus carthusianorum

Medicago lupulina

Asperula cynanchica

Phleum phleoides

Potentilla heptaphylla

Fragaria viridis

Origanum vulgare

Salvia verticillata

Stachys recta

Thymus praecox

Thesium linophyllon

Koeleria macrantha

Helianthemum nummularium ssp. obscurum

Poa compressa

Thymus marschallianus

Festuca rupicola

Carex pediformis

Geranium sanguineum

Brachypodium pinnatum

Stachys officinalis

Allium sennescens ssp.montanum

Galium boreale

Fig. 2. Species mobility groups distinguished on the basis of species turnover $(T)$ and carousel time $(C T)$ values. The A-C symbols denote the species with low, intermediate and high mobility respectively.

Dianthus carthusianorum L. Most of them have long-lived below-ground stems, that is why their vegetative growth is usually very slow (Table 1).

Group C comprised species with the highest mobility rates, such as Ranunculus bulbosus L., Sanguisorba minor Scop., Coronilla varia L., Euphorbia cyparissias L., Seseli and Scabiosa ochroleuca L. With the exception of the first two species, the high $R T$ and $C T$ values can be explained by their clonal growth type ("Rumex acetosella" and "Aegopodium podagraria" type, Klimeš et al. 1997.). In addition to vegetative re-sprouting, the persistent seed bank in the soil plays a significant role in the reproduction of some species belonging to this group (Ranunculus bulbosus, Euphorbia cyparissias) (Table 1).

Species mobility in plant communities is a very complicated process, because the observed pattern of species mo- bility is often only broadly related to life forms, clonal growth type, or life strategies of the studied species, particularly in the group with the lowest mobility (Klimeš 1999). However, Herbén et al. (1993), Law et al. (1993) and Tamm et al. (2002) showed a correlation between the mobility of species and the clonal growth type. These differences are probably the result of different scales in which the mobility of species was measured. The size of plots (1 $\mathrm{m}^{2}$ ) used in my research is much larger than the size of individuals of the majority of species (with the exception of Seseli libanotis). As a result, it was impossible to notice some changes connected with vegetative growth.

\section{Mobility of species in years}

The CA analysis of measured characteristics, as similar to the classification based of the $T, C T$ i $R T$ indices (Fig. 


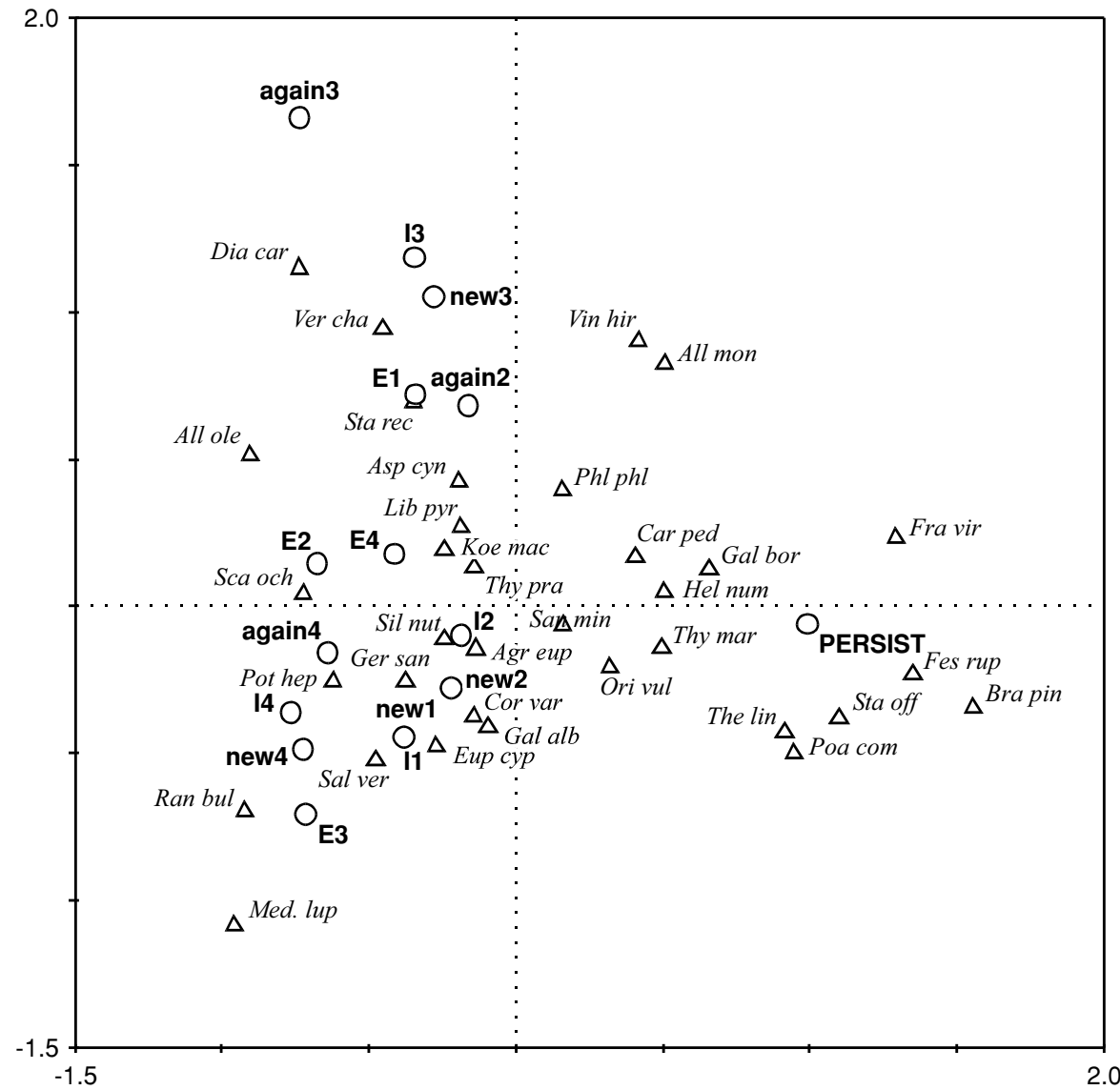

Fig. 3. The CA analysis of mobility characteristics of the 34 studies species. The first two axes $\left(\lambda_{1}=0.21, \lambda_{2}=0.07\right)$ explained 43.2 and $15.6 \%$ of variance in the data. Species names abbreviations as in Table 1. Abbreviations of explanatory variables as in Table 3; the numbers denotes 1997/1998 (1), 1998/1999 (2), 1999/2000 (3) and 2000/2001 periods respectively.
3), showed a distinct group of species which had a tendency to persist in a spot throughout all the study period. However, it also clearly showed the year-to-year changes in immigration and extinction rates. Most of the new colonizations of quadrates occurred in the second, third and fifth year (I1, I2 and I4 respectively, Fig. 3). Moreover, these species showed a decline in frequency in the 1999/2000 period (E3). The smallest group was formed by such species as Dianthus carthusianorum, Verbascum chaixii ssp. austriacum, Allium oleraceum or Asperula cynanchica, which colonized new sites in the fourth year (I3), but showed a strong decline in frequency in the second year of the study (E1). These changes were related to the year-to-year climatic changes during the study period, especially to changes in the mean annual precipitation (Bąba, unpublished data). In all the study period an increase in the immigration rate of species was related to the colonization of new sites rather than re-colonization of the previously occupied species, which can be explained by microsuccessional changes in a community as a result of species competition processes.

\section{The model of mobility of calcareous grassland}

As it was expected, the observed cumulative frequency of all the species under study was much lower than that expected under the random reassignment model (Fig. 4). Like Klimeš (1999), van der Maarel and Sykes (1997) and Palmer and Rush (2001), I also observed that the species had a tendency to occupy a given square for all the study period. It was obvious, because the investigated grassland was dominated by polycarpic perennial species. It was noticeable that the observed cumulative frequency of more than half of the investigated species was lower than it could be expected under the random immigration model; most of the species fell below the curve (Fig. 4). It was rather the result of the staying of species in a given place for the whole study period than the re-appearance in the previously occupied site. Some exceptions were Fragaria viridis Duchesne, Vincetoxicum hirundinaria Medik., Poa compressa L., Galium album Mill. subsp. album and Euphorbia, of which the patterns of dynamics almost exactly fitted this model.

\section{The interrelationships between the mobility indices}

Contrary to Palmer and Rusch (2001), I did not find statistically significant dependencies between the number of newly colonized quadrates by a given species and their mean frequency in the plot $(\mathrm{r}=0.220 ; \mathrm{p}=0.211$, r-Pearson's correlation coefficient), mean cumulative frequency $(\mathrm{r}=0.302 ; \mathrm{p}=0.08)$ and persistence of species in a quadrate $(\mathrm{r}=-0.06 ; \mathrm{p}=0.730)$. The colonization rate of new quadrates significantly influenced the time of residence in a quadrate (RT; r=-0.302, p=0.03; RRT; r=-0.386; p=0.03) and simultaneously the time of full carousel turnover (CT; $\mathrm{r}=0.480$, $\mathrm{p}=0.004$; RCT; $\mathrm{r}=0.473, \mathrm{p}=0.005)$.

As it was expected, the more frequently the species occurred, the higher was the probability of its persistence in the previously occupied spot $(\mathrm{r}=0.921, \mathrm{p}=0.0001)$. These species showed also a weak tendency to colonize the previously occupied patches $(\mathrm{r}=0.334, \mathrm{p}=0.05)$. At the same time the species with low frequency showed a high rate of space release. These results are contradictory to Caswell and Cohen (1991) and Rusch and Palmer' (2001) results, which showed no correlation between free space creation and species abundance. No significant correlation between 

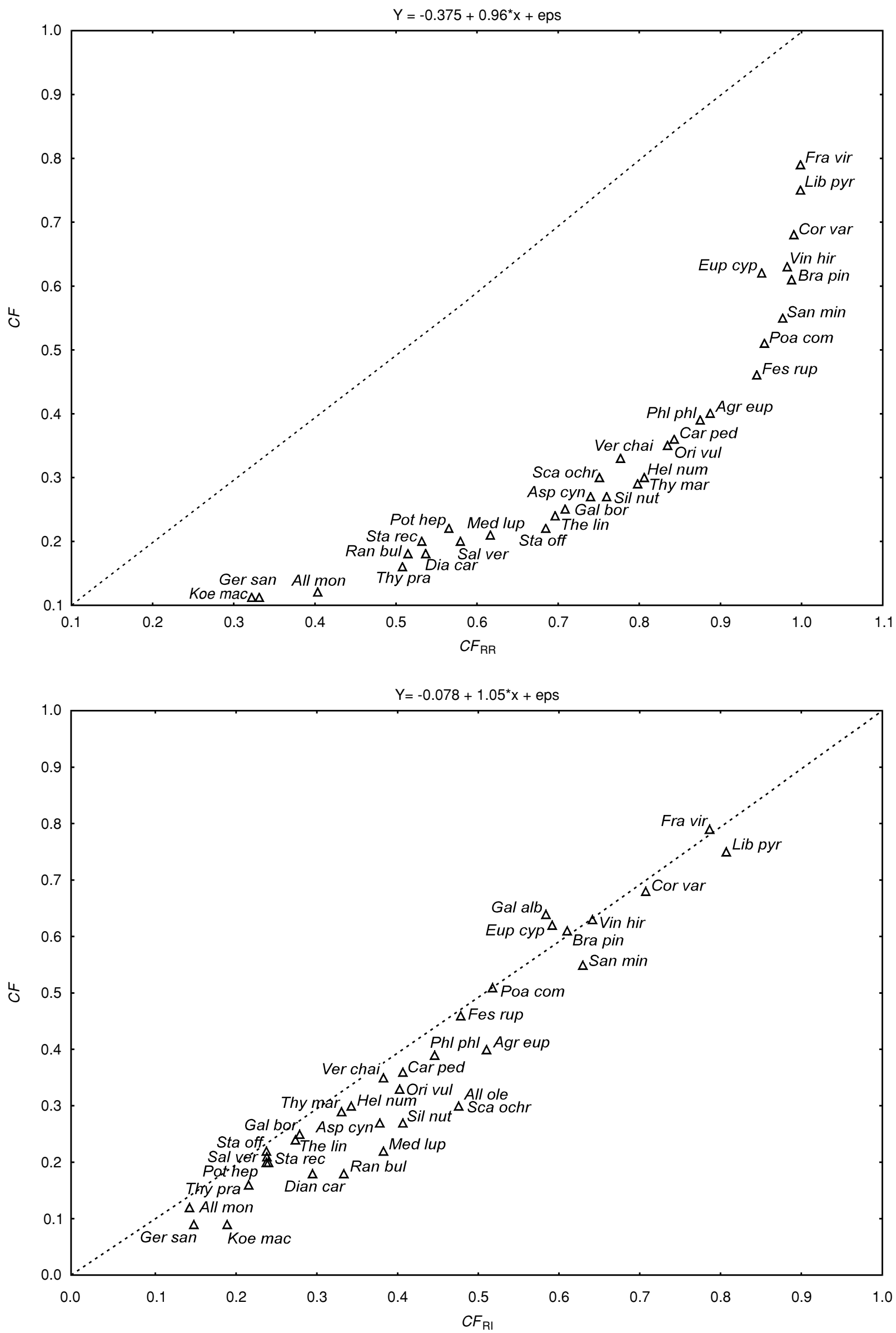

Fig. 4. The relationship of observed $(C F)$ and expected cumulative frequency of species under the random reassignment $\left(C F_{\mathrm{RR}}\right)$ and random immigration $\left(C F_{\mathrm{RI}}\right)$ models. Species names abbreviations as in Table 3. 
the immigration rate and space release $(\mathrm{r}=0.279 ; \mathrm{p}=0.110)$ was found, although some species: Thymus praecox, Stachys recta, Ranumculus, Scabiosa ochroleuca and Medicago lupulina showed simultaneously high values of $I$ and $E$. The duration of "full carousel turnover" was negatively correlated with immigration rate $(\mathrm{r}=-0.553, \mathrm{p}=0.001)$, turnover $(\mathrm{r}=-0.602, \mathrm{p}=0.001)$ and residence time $(\mathrm{r}=-0.581$, $\mathrm{p}=0.0001)$. The last value depended also on the number of repeated colonizations $(\mathrm{r}=-0.520, \mathrm{p}=0.001)$. Turnover rate, apart from the strictly numerical dependency on $I$ and $E$, showed a strong negative correlation with carousel time $(C T)$ and the mean time of persistence in quadrats $(R T)$ $(\mathrm{r}=-0.489, \mathrm{p}=0.003)$. A positive correlation of turnover with a mean cumulative frequency $(\mathrm{r}=0.353, \mathrm{p}=0.04)$ was found; however, it did not significantly depend on the mean frequency $(r=0.280, p=0.108)$.

\section{CONCLUSIONS}

The carousel model, as described by van der Maarel and Sykes $(1993,1997)$, with the only one "turnaround circle" does not fully explain the dynamics of the studied calcareous grassland. The results showed that the few matrix species had a very slow dynamics rate and seemed to determine the low dynamics of whole community on the plot scale. Some species, such as Galium boreale or Allium montanum, tended to move only within the particular parts of the plot, while others (for example Euphorbia cyparissias, Coronilla varia or Allium oleraceum) were able to "move around" the whole plot. The "complex carousel", as proposed by Maslov and van der Maarel (2000), in which these two types of species dynamics are included, was more explicit in the explanation of dynamics of the calcareous grasslands. However, since the measured indices of species mobility are strongly dependent on year-to-year changes, a long-term study is needed to get better parameters for the model.

\section{ACKNOWLEDGEMENTS}

I'm very grateful to Professor. S. Michalik, Dr hab. R. Kaźmierczakowa and the anonymous reviewers for valuable comments to the manuscript.

\section{LITERATURE CITED}

BOBBINK R., WILLEMS J.H. 1987. Increasing dominance of Brachypodium pinnatum (L.) Beauv. in chalk grasslands: A threat to a species-rich ecosystem. Biol. Conservation 40: 301-314 .

CASWELL H., COHEN J.E. 1991. Communities in patchy environments: a model of disturbance, competition and heterogeneity. In: Kolasa J., Pickett J.T.A (eds). Ecological heterogeneity, Springer, New York, pp. 92-122.

CZÁRÁN T., BARTHA S. 1992. Spatiotemporal models of plant community structure: competition between annuals and perennials. J. Theoretical Biol. 125: 475-489.

FRÖBORG H., ERIKSSON O. 1997. Local colonization and extinction of field layer plants in a deciduous forest and their dependence upon life history features. J. Vegetation Sci. 8: 395-400.

GEISSELBRECHT-TAFERNER L., GEISSELBRECHT J., MUCINA L. 1997. Fine-scale spatial population patterns and mo- bility of winter-annual herbs in a dry grassland. J. Vegetation Sci. 8: 209-216.

GLENN S.M., COLLINS S.L. 1992. Effect of scale and disturbance rates of immigration and extinction of species in prairies. Oikos 63: 273-280.

GRIME J.P. 2001. Plant strategies, vegetation processes and ecosystem properties. 2nd Edition. John Willey \& Sons, Chichester, pp. 456.

GRIME J.P., HODGSON J.G., HUNT R., THOMPSON K. 1995. The electronic comparative plant ecology. Chapman \& Hall, London.

GRUBB P.J. 1988. The uncoupling of disturbance and recruitment two kinds of seed bank and persistence of plant populations at the regional and local scales. Ann. Zoologici Fennici 25: 23-36.

HENSEN I. 1997. Life strategy systems of xerothermic grasslands - mechanisms of reproduction and colonization within Stipetum capillatae s.l. and Adonido-Brachypodietum pinnati. Feddes Repertorium 10,8 (5-6): 425-452.

HERBÉN T., KRAHULEC F., HADINCOVÁ V., KOVAROVÁ M. 1993. Small-scale spatial dynamics of plant species in a grassland community over six years. J. Vegetation Sci. 4: 171-178.

HERBÉN T., KRAHULEC F., HADINCOVÁ V., PECHACKOVÁ S. 1994. Is a grassland community composed of coexisting species with low and high spatial mobility? Folia Geobotanica et Phytotaxonomica 29: 459-468.

HERBÉN T., KRAHULEC F., HADINCOVÁ V., SKALOVÁ H. 1993. Small-scale variability as a mechanism for large-scale stability in mountain grasslands. J. Vegetation Sci. 4: 163-170.

HROUDOVÁ Z., PRACH K. 1994. The long-term changes of the relict steppe vegetation in the Bohemian Karst. Priroda, Praha 1: 63-729. (In Czech with English summary).

HUBER R. 1994. Changes in plant species richness in a calcareous grassland following changes in environmental conditions. Folia Geobotanica et Phytotaxonomica 29: 469-482.

KLEIN J. 1974. The meso- and microclimate of the Ojców National Park. Studia Naturae Ser.A, 8: 1-105.

KLIMEŠ L. 1999. Small-scale plant mobility in a species-rich grassland. J. Vegetation Sci. 10: 209-218.

KLIMEŠ L., KLIMEŠOVA J., HENDRIKS R., VAN GROENENDAEL J. 1997. Clonal plant architecture: a comparative analysis of form and function. In: H. De Kroon, Van Groenendael J. (eds), The ecology and evolution of clonal plants. pp. 129. Backhuys Publishers, Leiden, The Netherlands.

LAW R., MCLELLAN A.J., MAHDI A. 1993. Spatio-temporal processes in calcareous grassland. Plant Species Biol. 8: 175$-193$.

LEPŠ J., ŠMILAUER P. 2000. Multivariate analysis of ecological data. Česke Budéjovice, 168 pp.

MASLOV A., VAN DER MAAREL E. 2000. Limitation and extensions of the carousel model in boreal forest communities. Proceedings IAVS Symposium: 361-364.

MICHALIK S. 1979. Distribution of xerothermal and montane plants in the Ojców National Park depending on microclimatic conditions. Studia Naturae ser. A, 19: 1-96.

OTSUS M., ZOBEL M. 2002. Small-scale turnover in a calcareous grassland, its pattern and components. J. Vegetation Sci. 13: 199-206.

PALMER M.W., RUSCH G.M. 2001. How fast is the carousel? Direct indices of species mobility in an Oklahoma grassland. J. Vegetation Sci. 12: 305-318.

PÄRTEL M., ZOBEL K. 1995. Small-scale dynamics and species richness in successional alvar plant communities. Ecography 18: 83-90.

PARTYKA J. 2003. Temperatura i opady atmosferyczne na terenie w Ojcowskim Parku Narodowym (lata 1990-2000), msc.

RUSCH G., VAN DER MAAREL E. 1992. Species turnover and seedling recruitment in limestone grasslands. Oikos 63: 139-146. 
SYKES M.T., MAAREL E. VAN DER, PEET R.K., WILLEMS J.H. 1994. High species mobility in species-rich plant communities: an international comparission. Folia Geobotanica Phytotaxonomica. 29: 439-448.

TAMM A., KULL K., SAMMUL M. 2002. Classifying the clonal growth forms based on vegetative mobility and ramet longevity: a whole community analysis. Evolutionary Ecology 15: 383-401.

TER BRAAK C.J.F., ŠMILAUER P. 2002. CANOCO Reference Manual and CanoDraw for Windows User's Guide. Software for Canonical Community Ordination (version 4.5). Biometrics, Wageningen, Česke Budějovice.

THOMPSON K., BAKKER J.P., BEKKER R.M. 1997. The Soil Seed Banks of North West Europe: Methodology, Density and Longevity. Cambridge University Press, pp. 276.

TUTIN T.G., HEYWOOD V.H., BURGES N.A., VALENTINE D.H., WALTERS S.M., WEBB D.A. 1964-1995. Flora Europaea, 1-5, Cambridge University Press, Cambridge.
VAN DER MAAREL E. 1995. Vegetation dynamics and dynamic vegetation Acta Bot. Neerlandica 45: 421-442.

VAN DER MAAREL E. 1996. Pattern and process in the plant community: fifty years after A.S. Watt. J. Vegetation Sci. 7: $19-28$.

VAN DER MAAREL E., SYKES M.T. 1993. Small-scale plant species turnover in a limestone grassland: the carousel model and some comments on the niche concept. J. Vegetation Sci. 4: 179-188.

VAN DER MAAREL E., SYKES M.T. 1997. Rates of small-scale species mobility in alvar limestone grassland. J. Vegetation Sci. 8: 199-208.

VORONTZOVA L.I., ZAUGOLNOVA L.B. 1985. Population biology of steppe plants. In: White J. (eds), The population structure of vegetation. Handbook of Vegetation Science. Junk, Dordrecht, pp 143-178. 